\title{
Genetics and Epigenetics in Adult Neurogenesis
}

\author{
Jenny Hsieh ${ }^{1}$ and Xinyu Zhao ${ }^{2}$ \\ ${ }^{1}$ Department of Molecular Biology and Hamon Center for Regenerative Science and Medicine, \\ UT Southwestern Medical Center, Dallas, Texas 75390 \\ ${ }^{2}$ Department of Neuroscience and Waisman Center, School of Medicine and Public Health, \\ University of Wisconsin-Madison, Madison, Wisconsin 53705 \\ Correspondence: jenny.hsieh@utsouthwestern.edu; xzhao69@wisc.edu
}

The cellular basis of adult neurogenesis is neural stem cells residing in restricted areas of the adult brain. These cells self-renew and are multipotent. The maintenance of "stemness" and commitment to differentiation are tightly controlled by intricate molecular networks. Epigenetic mechanisms, including chromatin remodeling, DNA methylation, and noncoding RNAs (ncRNAs), have profound regulatory roles in mammalian gene expression. Significant advances have been made regarding the dynamic roles of epigenetic modulation and function. It has become evident that epigenetic regulators are key players in neural-stemcell self-renewal, fate specification, and final maturation of new neurons, therefore, adult neurogenesis. Altered epigenetic regulation can result in a number of neurological and neurodevelopmental disorders. Here, we review recent discoveries that advance our knowledge in epigenetic regulation of mammalian neural stem cells and neurogenesis. Insights from studies of epigenetic gene regulation in neurogenesis may lead to new therapies for the treatment of neurodevelopmental disorders.

In the adult vertebrate brain, the production of new neurons ("adult neurogenesis") takes place in local microenvironments or niches, such as the subventricular zone (SVZ) of the lateral ventricle and the subgranular zone (SGZ) of the dentate gyrus (DG) of the hippocampus (Gage 2000). A variety of signals, ranging from excitation, caused by locally released neurotransmitters, to systemic factors or drugs that cross the blood-brain barrier, converge on clusters of neural stem/progenitor cells (NSPCs) residing in these niches. Balanced control of self-renewal, differentiation, and survival of NSPCs produces new neurons and glial cells necessary for functional homeostasis of the brain, and also plays an important role in brain function, such as learning and memory. Moreover, as potential cancer stem cells, NSPCs are suspected to be the root of brain malignancies like glioblastoma multiforme. To become neurons, NSPCs require coordinated changes in the pattern of gene expression, primarily regulated at the level of gene transcription. Epigenetic mechanisms have emerged as an additional layer of regulation to fine-tune and coordinate gene expression during neurogenesis. Thus, signaling to the genome through diverse epigenetic regulatory mechanisms is critical to neurogenesis, during development and throughout life.

Editors: Fred H. Gage, Gerd Kempermann, and Hongjun Song

Additional Perspectives on Neurogenesis available at www.cshperspectives.org

Copyright (C) 2016 Cold Spring Harbor Laboratory Press; all rights reserved; doi: 10.1101/cshperspect.a018911

Cite this article as Cold Spring Harb Perspect Biol 2016;8:a018911 
Epigenetic mechanisms, including histone modification, chromatin remodeling, DNA methylation, and noncoding RNAs (ncRNAs), function as key regulators of gene expression (Fig. 1). The importance of epigenetic mechanisms has been appreciated for many years in the developmental and cancer biology fields. Indeed, drugs that act on epigenetic mechanisms are already in cancer clinical trials. Classical epigenetic processes, such as X-chromosome inactivation, imprinting, and gene silencing, have been studied in traditional model systems, such as plants, invertebrates, and mice. Epigenetic mechanisms are considered equally important to sequencespecific DNA-binding transcription factors as regulators of gene expression. Among the most commonly used definitions, epigenetics means meiotically and mitotically heritable changes in patterns of gene expression that are not encoded in the primary DNA sequence itself, essentially a term to describe alterations that lead to new cellular phenotypes without a change in genotype. In this sense, epigenetic changes in chromatin organization and biochemical modifications allow genotypically identical cells to behave phenotypically different.

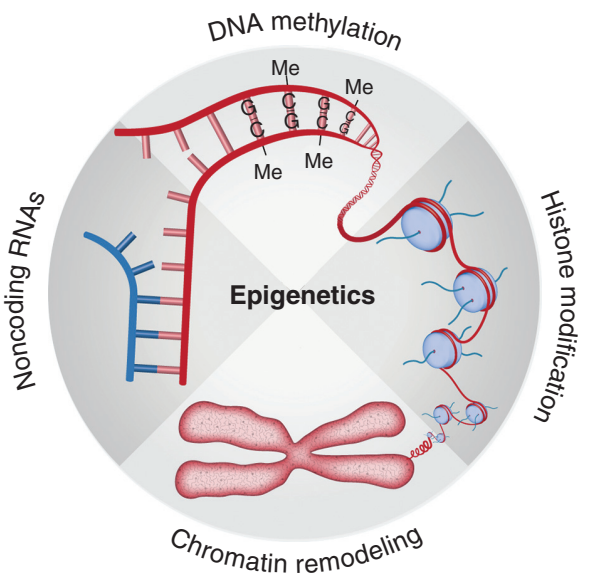

Figure 1. Four major categories of epigenetic mechanisms: histone modification, chromatin remodeling, DNA methylation, and noncoding RNAs (ncRNAs). The dynamic nature of epigenetic mechanisms offers an important layer of gene regulation, controlling the multiple steps of adult neurogenesis in response to environmental signals.
The regulatory controls of chromatin remodeling, as well as the potential stability of histone modifications and DNA methylation, make epigenetic regulatory mechanisms a prime candidate for mediating gene expression changes governing adult neurogenesis. In this article, we first present an overview regarding the principles of epigenetic regulation. Then, we dissect the four main categories of epigenetic mechanisms: histone modifications, chromatin structure, DNA methylation, and ncRNAs, and highlight recent studies describing adult neurogenesis under the control of epigenetic mechanisms. Finally, we end the article with a description of how epigenetic dysregulation may contribute to human neurodevelopmental disorders.

\section{CHROMATIN COMPLEXES CONTROLLING NEURAL CELL FATE AND NEUROGENESIS}

\section{Chromatin Structure and Histone Modifications}

Chromatin is a nucleoprotein complex comprised of nucleosome repeats of 147 base pairs (bp) of DNA sequence physically wrapped around two copies each of histone proteins $\mathrm{H} 2 \mathrm{~A}, \mathrm{H} 2 \mathrm{~B}, \mathrm{H} 3$, and H4 (Luger and Richmond 1998). Chromatin can exist in either highly condensed heterochromatin associated with gene silencing or loosely packed euchromatin associated with gene expression. One of the most exciting breakthroughs in chromatin biology in this last decade is the discovery that the amino-terminal tails of core histones are subject to a variety of covalent modifications, such as acetylation, methylation, ubiquitination, phosphorylation, ribosylation, and SUMOylation, and that DNA site- or domain-specific histone modifications ("the histone code") control the chromatin state and, therefore, the activation or repression of the associated genes (Jenuwein and Allis 2001; Bernstein et al. 2007). Some histone modifications (so-called "histone marks") like acetylation of lysine 9 and 14, di- or trimethylation of lysine 4 , and phosphorylation of serine 10 on histone $\mathrm{H} 3$ are signatures of actively expressed chromatin. Other marks, 
such as di- or trimethylation of lysine 9 or lysine 27 on histone $\mathrm{H} 3$ are associated with silent chromatin domains. The histone code is specified by chromatin-modifying enzymes, such as histone acetyltransferases (HATs), histone deacetylases (HDACs), histone methyltransferases (HMTs), and histone demethylases (HdMTs), which are targeted to specific chromatin loci through direct association with sequence-specific DNA-binding proteins in large, multicomponent complexes. Many of the components of these complexes, even the chromatin-modifying enzymes themselves, are signal responsive, resulting in a complex regulatory hierarchy for control of the genome.

The HATs and HDACs are the most extensively studied chromatin-modifying enzymes. HATs induce histone acetylation resulting in relaxation of the nucleosomes and increased transcription, whereas HDACs catalyze the reverse reaction. In the deacetylated state, nucleosomes are more condensed preventing access of transcriptional activators to their target sites resulting in transcriptional repression. There are 11 HDACs in mammals that are divided into four classes, class I, IIa, IIb, and IV, based on the classification of their yeast counterparts (de Ruijter et al. 2003). In addition to these classical HDACs, another group of deacetylases, called the sirtuins, are sometimes referred to as class III HDACs, which will not be discussed here. Class I and IIa HDACs have been examined in the context of NSPC biology. Class I HDACs (HDACs 1, 2, 3, and 8) are believed to be ubiquitously expressed, although cell-lineage-specific expression patterns have been found for both HDAC1 and HDAC2 (MacDonald and Roskams 2008). Class IIa HDACs (HDACs 4, 5, 7, and 9) are able to shuttle between nucleus and cytosol and display interesting cell-type-specific expression. For example, HDACs 3 and 5 are highly expressed in NSPCs and required for their proliferation, maintenance, and differentiation (Sun et al. 2007; Schneider et al. 2008; Jiang and Hsieh 2014). HDACs 4, 5, 7, and 9 are up-regulated in differentiating NSPCs (Ajamian et al. 2003). Therefore, cell-type-specific HDACs may serve as important regulators in NSPCs and neuronal development, although their roles are not fully clear. One important clue regarding the role of class I and class II HDACs comes from studies of small molecule HDAC inhibitors (HDACi), such as trichostatin $A$ and valproic acid (VPA) (Grozinger and Schreiber 2002). HDACi can induce neuronal differentiation in embryonic (Hao et al. 2004), as well as adult neural progenitor cells (Hsieh et al. 2004). Despite the work nearly a decade ago demonstrating that HDACi promotes adult neurogenesis (Hsieh et al. 2004), the function of individual HDACs in adult neurogenesis is largely unresolved. HDAC1 and HDAC2 play redundant roles in many different systems, such as adipogenesis, oligodendrocyte differentiation, and progression of neural precursors to neurons during brain development (Montgomery et al. 2009; Ye et al. 2009; Haberland et al. 2010). In these studies, the investigators did not observe a dramatic phenotype with single deletion of HDAC1 or HDAC2, but HDAC1/ HDAC2 double knockout mice show severe defects. Considering that both HDACs 1 and 2 are members of class I HDACs, they are speculated to play redundant roles in the developing and adult brain. Nevertheless, one study showed that overexpression of HDAC2, but not HDAC1, in neurons resulted in defects in hippocampus-dependent memory formation by using Pavlovian fear conditioning and Morris water-maze tests (Guan et al. 2009). Another study showed that HDAC2 deletion, both globally as well as conditionally in radial glia-like stem cells using a GLAST-CreER $^{\mathrm{T} 2}$ driver line, had a severe impact on the maturation and survival of adult-generated neurons in the SGZ and SVZ (Jawerka et al. 2010). Recently, it was shown that loss of HDAC3 in adult NSPCs leads to $\mathrm{G}_{2} / \mathrm{M}$ cellcycle defects and decreased neural progenitor proliferation, suggesting that different HDACs control distinct stages of adult neurogenesis (Jiang and Hsieh 2014). Although more studies on HDACs will shed light on their exact functions in adult neurogenesis, it is tempting to speculate that pharmacological inhibition of HDAC activity might become an effective clinical strategy for treating disorders related to adult neurogenesis, such as cognitive decline, and promote neural repair. 
Methylation of histones on lysine or arginine residues is catalyzed by HMTs, which might be associated with either gene silencing or activation, depending largely on the position of the methylated residues and sometimes on the number of methyl groups added (me1, me2, and me3) (Mosammaparast and Shi 2010). The discovery of HdMT enzymes that actively remove methyl groups from histones has provided direct evidence that histone methylation is a dynamic and reversible process (Mosammaparast and Shi 2010). The first discovered HdMT, lysine-specific demethylase 1 (LSD1), also known as lysine (K)-specific demethylase1A (KDM1A) (Shi et al. 2004b). HdMTs are known to regulate neuronal differentiation and fate specification, whereas mutations of HdMTs have been tied to $\mathrm{X}$-linked mental retardation (XLMR) and many cancers (Pedersen and Helin 2010). In neural progenitors, the proliferation of neural progenitors requires the orphan nuclear receptor TLX (Shi et al. 2004a; Zhang et al. 2008). At least, until now, the mechanism of TLX was elusive. More recently, TLX was shown to recruit LSD1 together with another histone deacetylase HDAC5, which were recruited to the promoter regions of the cell-cycle inhibitor p21 gene and tumor suppressor phosphatase and tensin homolog (Pten) gene to repress their expression and maintain the proliferative state (Shi et al. 2004b). Interestingly, lentiviral-mediated small interfering RNA (siRNA) knockdown of LSD1 in cultured adult NSPCs and in adult mouse DG resulted in fewer bromodeoxyuridine $(B r d U)^{+}$cells (Sun et al. 2010), consistent with the key role of TLX in maintaining neural progenitor proliferation. These results highlight the complex interplay between transcription factors and nuclear epigenetic mechanisms, such as histone modification marks and ncRNAs, in control of adult NSPC proliferation.

Additional evidence for the role of histone methylation in adult neurogenesis comes from recent experiments involving members of the polycomb (PcG) and trithorax (TrxG) group of proteins (Bernstein et al. 2007). The PcG protein Bmil is required for maintenance of self-renewing NSPCs, but not transit-amplifying progenitors, in the adult SVZ (Molofsky et al. 2003). Building on these findings, mixed-lineage leukemia 1 (Mll1), a TrxG member that encodes an $\mathrm{H} 3 \mathrm{~K} 4$ methyltransferase, is required for neuronal differentiation (Lim et al. 2009). However, Mll1 knockout mice showed normal gliogenesis. On closer inspection, these investigators showed neurogenesis was severely impaired in Mll1 knockout mice because of the down-regulation of the Mll1 target gene Dlx2, which was previously described to function in interneuron development (Long et al. 2007). Interestingly, loss of Mll1 did not affect the level of H3K4 methylation at the Dlx2 promoter, but H3K27 methylation was increased. Given that JmjC domain-containing H3K27 demethylases, UTX and JMJD3, can form complexes with H3K4 methyltransferases (Hong et al. 2007; Issaeva et al. 2007), it would be interesting to see whether the phenotype observed in the Mll1 knockout is caused by a failure to recruit JMJD3, thus resulting in enhanced $\mathrm{H} 3 \mathrm{~K} 27$ methylation. Also, it would be interesting to compare the function of PcG and TrxG genes in adult hippocampal neurogenesis. The many types of histone modifications, which can occur on different histone residues, plus the identification of many HMTs and demethylases, suggest an intricate molecular mechanism regulating neuronal differentiation, survival, and maturation.

\section{Chromatin Complexes in Neural-Cell-Fate Specification and Neurogenesis}

In addition to the activity of histone-modifying enzymes, multisubunit protein chromatin remodeling complexes are also recruited to gene-specific promoters by association with DNA-binding proteins (Grozinger and Schreiber 2002). During cortical development, NSPCs first undergo limited expansion through rounds of symmetric divisions, and then undergo neurogenesis, mainly through asymmetric divisions (Temple 2001). Toward the end of neurogenesis, cortical progenitors switch back to symmetric divisions and give rise to astrocytes and oligodendrocytes. Cell-fate specification toward neuronal or glial lineages involves the reciprocal regulation of several gene batteries. For example, the genes responsible for the specification of 
neuronal cells must be repressed or silenced when the developing NSPCs diverge toward astrocytic or oligodendrocytic cell fate, and vice versa, gliogenic genes must be inhibited during neurogenesis. This is coordinated through both transcriptional and epigenetic regulatory mechanisms that determine the potential of the cell to respond to extrinsic signals (Fig. 2). Many transcription factors with known roles during development re-emerge to play key roles in neural progenitor specification and differentiation in adult neurogenic niches (for recent reviews, see Guillemot 2005; Hodge et al. 2012; Hsieh 2012).

Several chromatin-remodeling factors have been reported to play key roles during neural development, including members of the SWI/ SNF family of chromatin-remodeling complexes (Cui et al. 2006; Lee et al. 2006). SWI/SNF complexes use ATP hydrolysis to disrupt histone-DNA associations and contain different combinations of proteins that include both conserved and nonconserved components (Bec- ker and Horz 2002). They also interact with HATs or HDACs and/or sequence-specific transcription factors to activate or repress target genes. Typically, SWI/SNF complexes contain either ATPase Brahma (Brm) or Brahma-associated factors (BAFs). Chromodomain proteins, which possess the ATPase domain found in SWI/SNF proteins, are also recruited by PcG repressors, and are involved in homeotic gene silencing to control tissue patterning.

Recently, BAFs have been implicated in neural development and adult neurogenesis. The transition of multipotent progenitors to postmitotic neurons involves an essential switch in ATP-dependent complexes: the BAF45a and BAF53a subunits are exchanged for the homologous BAF45b and BAF53b subunits. Proliferation of E14.5 cortical progenitors is dependent on individual BAF subunits (BAF45a and/or BAF53a) (Lessard et al. 2007). Notably, mice lacking the core subunit Brg, which is associated with BAF45a and BAF53a, displayed reductions in cortical thickness and decreased proliferation

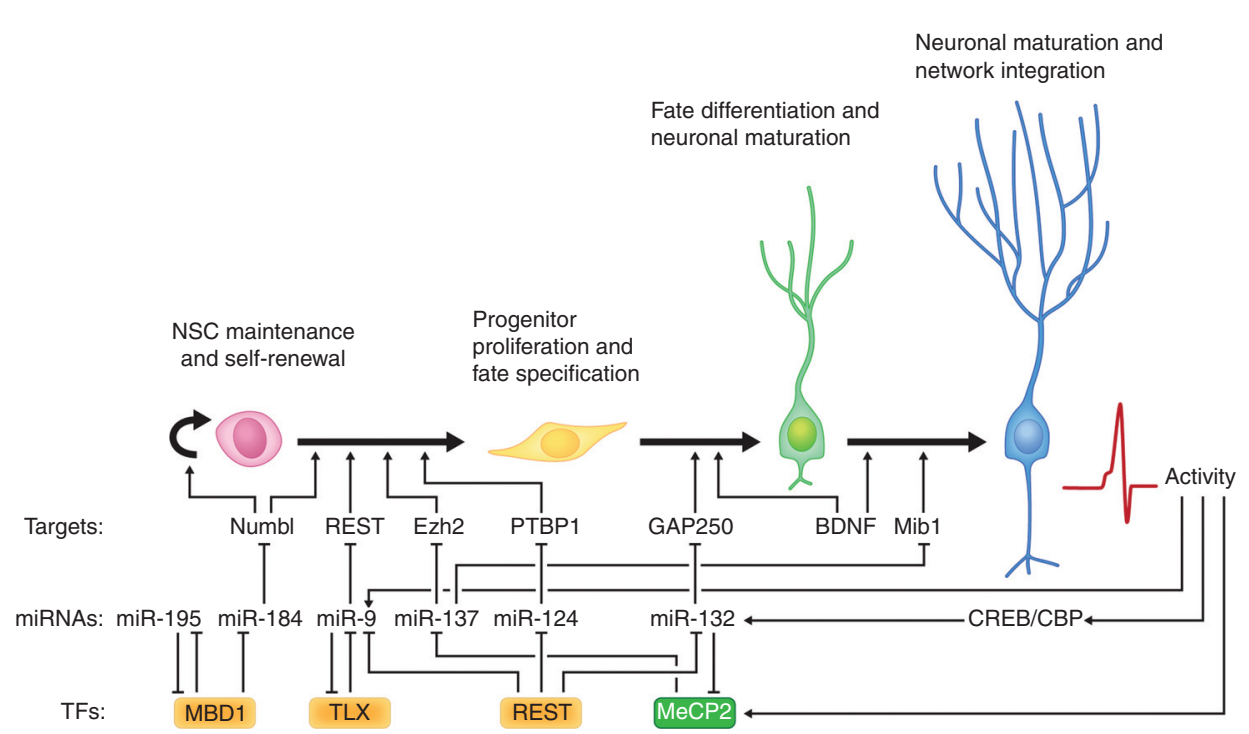

Figure 2. Cross talk between transcription factors and epigenetic mechanisms to control neurogenesis. Transcription factors (TFs) regulate the expression of microRNAs (miRNAs), which, in turn modulate various downstream targets to control the different stages of adult neurogenesis. This extensive cross-regulation between TFs, miRNAs, and their messenger RNA (mRNA) targets is essential to maintain homeostasis of neural stem/ progenitor cells (NSPCs) and the production of new neurons in the adult mammalian brain. NSC, Neural stem cell; BDNF, brain-derived neurotrophic factor; CREB, cAMP-response element-binding protein; CBP, CREBbinding protein; $\mathrm{MBD}$, methyl-binding domain. 
of progenitors. Recently, a provocative study reported a microRNA-based mechanism (to be described in more detail in a later section) that controls the essential BAF subunit composition switch. Specifically, miR-9* and miR-124 are necessary to repress BAF53a as neural progenitors differentiate into neurons (Yoo et al. 2009). Moreover, expression of REST/NRSF (described below) represses miR-9* and miR-124, leading to the derepression of BAF53a in postmitotic neurons. These results underscore the interplay between transcriptional regulators and regulatory ncRNAs, which will be discussed in the next section. In adult neural progenitors, the BAF complex has been recently shown to interact with Pax6 to establish a neurogenic cross-regulatory transcriptional network in adult SVZ neurogenesis (Ninkovic et al. 2013). Interestingly, $\mathrm{Brg} 1$ is required for neuronal lineage commitment; the absence of Brg1 in the adult SVZ causes the conversion of neuroblasts in the rostral migratory stream and olfactory bulb to the glial lineages. Together, these data indicate the important role of chromatin remodeling factors in adult neurogenesis.

Besides the activation of gene expression, transcriptional repression may be equally important to prevent undesired cell fates. A candidate master negative regulator for neurogenesis and gliogenesis is the transcriptional regulator NRSF/REST (Chong et al. 1995; Schoenherr and Anderson 1995). Initially described as a repressor of neuronal genes in nonneuronal cells, NRSF/REST is a zinc finger protein that binds to a conserved 21-23 bp motif known as NRSE (neuron-restrictive silencing element, also called RE1). The NRSE/RE1 sequence is found scattered throughout the genome, many in the regulatory regions of neuron-specific genes, including neuronal growth factors, ion channels, neurotransmitter receptors, and guidance/migration molecules, among other important neurogenic genes. Cumulating evidence suggests that NRSF/REST functions by recruiting other corepressor complexes, such as mSin3A/B (Naruse et al. 1999), N-CoR (Jepsen et al. 2000), CtBP (Garriga-Canut et al. 2006), or CoREST (Ballas et al. 2001), to specific RE-1 sites in the genome. Importantly, these reg- ulatory complexes also recruit chromatin-modifying class I HDAC enzymes to the genome. Bioinformatics analyses have identified hundreds to thousands of NRSE sites throughout the mammalian genome (Bruce et al. 2004) supporting the idea that NRSF/REST functions as a master regulator of neuronal gene expression in NSPCs as well as in mature neurons (Sun et al. 2005; Greenway et al. 2006). In terms of function, our recent work showed that NRSF/REST is required for the maintenance of the adult NSPC pool and to prevent precocious neuronal differentiation (Gao et al. 2011). These results suggest that REST/NRSF is a key mediator of the cross talk between niche signals to the epigenome to control NSPC maintenance.

The world of chromatin remodeling and histone modifications is becoming increasingly complex and fascinating. For example, histone arginine methylation has been shown to regulate the pluripotent state of cells in the inner cell mass, and intriguingly may be among the first set of marks that contribute to the pluripotent state (Torres-Padilla et al. 2007). These types of studies will likely extend to adult neurogenesis, in which stem cells still retain multipotency, but are no longer pluripotent. Understanding both the epigenetic and genetic determinants of plasticity is important for determining how to use and manipulate stem cells for regenerative medicine.

\section{THE ROLE OF DNA METHYLATION AND DEMETHYLATION IN NEUROGENESIS}

Another classic epigenetic modification implicated in adult neurogenesis is DNA methylation, in which mammalian DNA can be covalently modified through methylation of the carbon at the fifth position on the pyrimidine ring of the cytosine residue, which is usually found at symmetrical CpG dinucleotides. DNA methylation is a major epigenetic mechanism for the establishment of parental-specific imprints during gametogenesis and gene silencing of the inactivated $\mathrm{X}$ chromosome and retrotransposons (Jaenisch and Bird 2003). DNA methylation is mediated by cellular methyl- 
transferases, DNMT3a and DNMT3b, which adds methyl groups de novo onto unmethylated DNA. When cells divide, the methyltransferase DNMT1 preferentially recognizes hemimethylated DNA and maintains DNA methylation. Interestingly, both classes of methyltransferases have been shown to participate in various stages of neural fate specification and neurogenesis. During the neural induction of embryonic stem cells (ESCs) to NSPCs, many pluripotency genes are methylated and silenced, supporting the importance of DNA methylation during neurogenesis (Mohn et al. 2008). DNMT3a and DNMT3b are critical for specification of neurons and glia (Feng et al. 2005), as well as during later stages of neuronal maturation and function (Levenson et al. 2006; Feng et al. 2010). DNMT1 is involved in JAK-STAT signaling to control the timing of when precursor cells switch from neurogenesis to gliogenesis during development (Fan et al. 2001, 2005), as discussed below.

A limited number of cases indicate that sitespecific DNA methylation is important for cellular differentiation. During embryonic development, astrocyte differentiation and activation of the glial fibrillary acidic protein (GFAP) promoter requires binding of the signal transducer and activator of transcription 3 (STAT3) in response to leukemia inhibitory factor (LIF) signaling (Ross et al. 2003). Early cortical progenitors are refractory to astrocyte fates, even in the presence of LIF and STAT3-activation, likely because of methylation of the STAT3-binding site, which prevents STAT3 binding to the GFAP promoter (Takizawa et al. 2001). At later stages, this site becomes demethylated and gliogenesis can proceed. A similar case was observed in the STAT3-binding site of the S100 $\beta$ promoter, a calcium-binding protein expressed in astrocytes (Namihira et al. 2004). In adult neurogenic regions, electroconvulsive shock or physical exercise (e.g., running)-induced neuronal activation can modify DNA methylation status of specific promoter sites of a number of genes including $B d n f$, leading to altered expression of this neurotrophic factor, which may be responsible for increased neurogenesis (Guo et al. 2011a). We have found that hypomethylation of $F g f 2$ promoter is directly associated with elevated fibroblast growth factor (FGF)-2 protein expression and increased proliferation but reduced differentiation in adult NSPC proliferation isolated from MBD1-deficient mice ( $\mathrm{Li}$ et al. 2008).

DNA methylation has long been considered as a static DNA modification, with demethylation occurring only passively (Ooi et al. 2009; Chen and Riggs 2011). Ma and colleagues (2009) recently discovered that neuronal activity-dependent demethylation occurs in the adult DG, which is mediated by a DNA excision repair protein, Gadd45b. The same group then showed that such demethylation might be mediated by a common pathway that involves 5hydroxymethylation of cytosine $(5 \mathrm{hmC}$ ) (Guo et al. 2011b). A series of studies have shown that $5 \mathrm{hmC}$, although existing at much lower levels compared with $5 \mathrm{mC}$, is particularly abundant in brain tissue and ESCs (for a recent review, see Shen and Zhang 2013). Direct breaking of the strong covalent bond between methyl group and cytosines seems impossible; therefore, the current model of active DNA demethylation involves multistep chemical reactions by several groups of proteins. Among them, the ten-eleven translocation (TET) proteins that change methylated cytosines $(5 \mathrm{mC})$ to $5 \mathrm{hmC}$ by hydroxylation and further produce $5 \mathrm{fC}$ and $5 \mathrm{caC}$ by oxidation, have been shown to be critical for the production of $5 \mathrm{hmC}$ and DNA demethylation. Other proteins include activation-induced deaminase (AID), a deaminase family that can deaminate the base of $5 \mathrm{mC}$ or $5 \mathrm{hmC}$ and uracil-DNA glycosylase (UDG) family of base excision repair (BER) glycosylases that can remove 5 hmC via DNA-repair mechanisms (Koh and Rao 2013). Literature suggests that hydroxymethylation may play important roles in maintaining the pluripotency of embryonic stem cells, regulating activity-dependent gene expression in the brain and mediating dynamic gene expression changes during brain development (Guo et al. 2011b; Szulwach et al. 2011; Wang et al. 2012). A recent study reported that Tet1 mutant mice also show adult neurogenesis deficits and impairment in learning and memory (Zhang et al. 2013). However, how 5-hydroxymethylation and DNA demethyl- 
ation regulate neurogenesis remain to be investigated.

Another mechanism by which DNA methylation leads to transcriptional gene silencing is the binding of methyl-CpGs by methyl-CpGbinding proteins (MBPs), which further recruit other regulatory complexes, leading to gene inactivation. The MBP family is divided into three subgroups: methyl-binding domain (MBD) family including MBD1-5 and MeCP2; Kaiso family of methyl-CpG binding zinc fingers; and UHRF1 and 2 proteins containing the SET and RING finger-associated domain (SRA) (Defossez and Stancheva 2011); several of these are enriched in the brains with highest expression in mature neurons. We have shown that both MBD1 and MeCP2 are expressed in NSPCs, immature neurons, and mature new neurons in the adult brain. Deficiency of MBD1 leads to reduced production and maturation of new neurons (Zhao et al. 2003; Liu et al. 2010; X Zhao, unpubl.), whereas deficiency of MeCP2 leads to delayed maturation and impaired dendritic and spine morphogenesis of new neurons (Smrt et al. 2007, 2011). The function of MeCP2 in pluripotent-stem-cell differentiation has also been explored by using patient-derived-induced pluripotent stem cells (iPSCs) and the results further support the importance of MeCP2 in maturation stages of neuronal development (Marchetto et al. 2010; Ananiev et al. 2011; Kim et al. 2011; Farra et al. 2012).

Therefore, dynamic DNA methylation catalyzed by DNMTs and interpreted by MBPs have significant roles in NSPC maintenance, fate specification, and adult neurogenesis. With the advancement of whole-genome analysis at the single-base level in small numbers of cells, we will obtain a clearer picture in this regard.

\section{NONCODING RNAs REGULATE NEURAL STEM CELLS AND NEUROGENESIS}

Only less than $3 \%$ of the human genome codes for protein whereas more than $80 \%$ of the genome is transcribed into RNAs, suggesting potential roles for ncRNAs in cellular functions (Jobe et al. 2012). To date, various types of
ncRNAs have been discovered with the number still increasing and many of them are enriched, if not specific, to the brain. The broad ncRNA category includes several types of small ncRNAs and long ncRNAs (lncRNAs, >200 bases) (Wapinski and Chang 2011; Jobe et al. 2012).

Small ncRNAs include microRNAs (miRNAs), small nucleolar RNAs (snoRNAs), siRNAs, and PIWI-interacting RNAs (piRNAs). The discovery of small ncRNAs has revolutionized our understanding of the mechanisms that regulate gene expression in all cells (Novina and Sharp 2004), including those in the mammalian brain (Cao et al. 2006). Their small size and sequence complementarity allow extreme versatility to target messenger RNAs (mRNAs) for repression or activation of gene expression or chromatin structural modification of targeted genes. Among ncRNAs, miRNAs are the best studied both in terms of their expression profiles and functions. In the canonical miRNA-processing pathway, the precursor of miRNAs (pre-miRNA) are transcribed from the genome and processed by DGCR8 and Drosha to release the stem-loop pre-miRNA. The pre-miRNA is exported from the nucleus and processed to a mature 20- to 22-nucleotide-long double-stranded miRNA by Dicer. DGCR8, Drosha, and Dicer are RNase III family RNA-processing enzymes and key components for biogenesis of most miRNAs (Krol et al. 2010). miRNAs can bind its target mRNAs through partial base pairing between its 6- to 8-nucleotide long seed sequence and recruits RNA-induced silencing complex (RISC), to degrade the mRNA or to repress protein translation. A single miRNA may have hundreds of downstream targets (Bartel 2009). To date, more than 1500 miRNAs have been discovered in mammals. A number of miRNAs are known to play important roles in stem cells and development. For example, miR-9 and miR-124 are enriched in the brain compared with other tissues. In fact, they are among the most abundant miRNAs in the central nervous system (CNS). The levels of miR-124 increase during neuronal differentiation and miR-124 promotes neuronal differentiation through its downstream targets, such as splicing regulatory factor Ptbp1, proneuronal factors Ngn1 and 
NeuroD1, and REST/NRSF (Conaco et al. 2006; Makeyev et al. 2007; Visvanathan et al. 2007; Cheng et al. 2009; Yoo et al. 2009; Liu et al. 2011). The importance of miRNAs in neurogenesis is further supported by the observation that mice lacking Dicer, Drosha, and DGCR8 are all embryonic-lethal (Park et al. 2010). Conditional knockout of these genes in mice leads to various neurogenic phenotypes during embryonic cortical neurogenesis (De Pietri Tonelli et al. 2008; Knuckles et al. 2012). GDCR8 heterozygote mice show reduced cell proliferation and neurogenesis in adult hippocampus, which can be partially rescued by insulin-like growth factor (IGF)-2 (Ouchi et al. 2013). We found that several miRNAs, including miR-137, miR-184, and miR-195 have significant regulatory roles in adult hippocampal neurogenesis (Szulwach et al. 2010; Liu et al. 2010, 2013).

Recently, lncRNAs are coming into the center stage of stem cells and neural plasticity, although their mechanisms of action are diverse and largely unknown (Wapinski and Chang 2011; Ng et al. 2013b). lncRNAs range in size from 200 to 10,000 bases and may undergo splicing and polyadenylation, similar to protein coding mRNAs (Wang and Chang 2011). The human genome may have more than 30,000 lncRNAs and at least half of these are expressed in the CNS with some of them showing dynamic expression patterns during cellular differentiation and brain development (Mercer et al. 2008). Although largely unexplored, current literature suggests that lncRNAs can regulate gene expression at many levels including chromatin structural maintenance and mRNA targeting (Wang and Chang 2011). IncRNAs have also been shown to play functional roles; for example, in GABAergic interneuron development and function. lncRNAs also likely play a role in adult hippocampal neurogenesis. In a recent study by Ramos et al. (2013), 8992 lncRNAs encoded from 5731 loci were identified from microdissected DG and SVZ, and 2108 of them are novel transcripts. The investigators show that shRNA-mediated knockdown of two such lncRNAs, Six3os and Dlxlas leads to decreased neuronal but increased astrocyte differentiation in adult NSPCs. Another lncRNA, named rhabdomyosarcoma 2-associated transcript (RMST) has been identified as being required for neuronal differentiation of neural progenitors by recruiting the neural progenitor transcription factor Sox2 to gene promoters ( $\mathrm{Ng}$ et al. 2013a) However, little is known about lncRNA expression in NSCs in the adult DG. Moreover, the research linking lncRNA expression to brain development and cell lineage specification strongly suggests that studying lncRNAs in adult neurogenesis will be a productive pursuit.

With the majority of the mammalian genome transcribed into ncRNAs, these ncRNAs likely have important roles in cell fate and neuronal development. With better transcriptome analysis and advanced bioinformatics, we will likely discover more diverse and novel noncoding transcripts in the near future.

\section{EPIGENETIC DYSFUNCTION AND NEURODEVELOPMENTAL DISEASES}

Given the importance of epigenetic regulation, it is not surprising that alterations in this process led to human neurological disorders. In fact, many HMTs are associated with cancer (reviewed in Albert and Helin 2010) and neurodevelopmental diseases, including Sotos syndrome, Wolf-Hirschhorn syndrome, Rubenstein-Taybi syndrome and 9q syndrome (Nimura et al. 2010).

Rett syndrome is one of the first neurodevelopmental disorders with epigenetic basis. Rett patients are characterized by normal development until 1 year of age, most commonly seen in females, and is followed by a rapid deterioration, involving loss of speech and motor skills, microcephaly, seizures, autism, ataxia, and stereotypical hand wringing (Rett 1966). The seminal discovery of X-linked MECP2 as the gene for Rett syndrome has brought the epigenetic regulation to the frontlines of neurodevelopmental research (Amir et al. 1999). $\mathrm{MeCP} 2$, a reader of DNA methylation, is found highly enriched in postmitotic neurons (Zoghbi 2003). Mutations of MeCP2 are also found in a subset of autism spectrum disorders (Amir et al. 1999; Guy et al. 2001; Jung et al. 2003; Neul et al. 
2008). Because MeCP2 is expressed widely in many types of neurons in the brain and Rett patients show complex symptoms both in severity and in time course, to study how MeCP2 regulates neurodevelopment has been challenging. Taking advantage of the simplicity of adult neurogenesis in which only one type of neuron is generated in a small quantity (Ming and Song 2005; Li and Zhao 2008) allowing for single-cell tracking, we analyzed the function of MeCP2 during neurogenesis and neuronal maturation. We discovered that MeCP2 is expressed at a low level in immature NSPCs and intermediate progenitor cells (IPCs) but its expression levels increase during neuronal differentiation and reaches the highest level in mature neurons (Smrt et al. 2007, 2010, 2011).

Much less is known about MBD1. We are the first group to investigate the function of MBD1 in the brain (Zhao et al. 2003). We discovered that MBD1 is expressed widely in neurons in the adult brain. In the adult DG, in which adult neurogenesis persists, MBD1, like $\mathrm{MeCP} 2$, is expressed in Nestin-positive NSCs and IPCs, doublecortin (DCX)-positive immature neurons, and NeuN-positive mature neurons. The absence of MBD1 leads to significantly reduced number and impaired maturation of new neurons (Zhao et al. 2003; Li et al. 2008; Liu et al. 2010). We have shown that MBD1 null mice display autism-like behavioral deficits, such as impaired social interaction, stereotypic behavior, deficient learning, reduced sensory motor gating, and increased anxiety and depression (Zhao et al. 2003; Allan et al. 2008). Corroborating our observations, $M B D 1$ gene mutations and polymorphisms have been found in a subset of autistic patients and the presence of MBD1 mutations is correlated with more severe cognitive phenotypes ( $\mathrm{Li}$ et al. 2005; Cukier et al. 2010). Thus, $M B D 1$ is considered an autism-associated gene (SFARI Gene database, see sfari .org/resources/sfari-gene). Deletion of chromosome $18 \mathrm{q} 21$ containing $M B D 1$ gene is also associated with mental retardation (Feenstra et al. 2007; Kato et al. 2010). With the progress of genetic diagnosis and sequencing efficiency, it is likely that additional $M B D 1$ mutations or polymorphisms will be discovered.
Another commonly inherited intellectual disability is fragile $\mathrm{X}$ syndrome. Patients have excessive expansion of the CGG sequence from the $5^{\prime}$ UTR of the FMR1 gene, resulting in methylation of the repeats and the FMR1 promoter, hypoacetylation of associated histones, and chromatin condensation. Consequently, there is transcriptional silencing of the gene and absence of functional fragile $\mathrm{X}$ mental retardation protein (FMRP). However, the mechanism and timing of methylation and gene silencing is not well understood. One proposed therapeutic strategy for individuals with fragile $\mathrm{X}$ has been to demethylate the gene to restore expression of FMR1. Treatments with the DNA demethylating drug 5-aza-2-deoxycytidine (5-azadC) has resulted in decreased histone $\mathrm{H} 3$ methylation at the lysine 9 residue, increased $\mathrm{H} 3$ and $\mathrm{H} 4$ acetylation, and decreased methylation at $\mathrm{H} 3$ lysine 4, resulting in the partial activation of FMR1 (Tabolacci et al. 2005, 2008). Studies have shown that treatment of human fragile X lymphoblastoid cell lines with 5 -azaC results in reactivation of the FMR1 gene and FMRP expression (Chiurazzi et al. 1998, 1999; Coffee et al. 1999). HDAC inhibitors can also increase FMR1 mRNA and protein expression, albeit at levels much less than controls (Coffee et al. 1999; Biacsi et al. 2008). It appears that MeCP2 and Brm can associate and jointly silence the Fmrl gene. RNAi knockdown of MeCP2 and Brm resulted in increased mRNA transcription of Fmrl (Harikrishnan et al. 2005). We recently showed that FMRP has a significant role in NSC fate specification during adult neurogenesis. Deletion of FMRP either globally or only in adult-born neurons leads to impaired learning in mice whereas restoration of FMRP only in adult-born neurons can rescue certain hippocampal specific learning deficits (Luo et al. 2010; Guo et al. 2011c, 2012, 2015).

Recently, lncRNAs have also been linked to neurological diseases (Qureshi and Mehler 2013). A comparison of postmortem brain tissue identified 222 lncRNAs with changes in expression in the autistic group (Ziats and Rennert 2013). Prader-Willi syndrome, a genetic disorder of obesity, intellectual disability, and sleep abnormalities, is caused by loss of lncRNAs on 


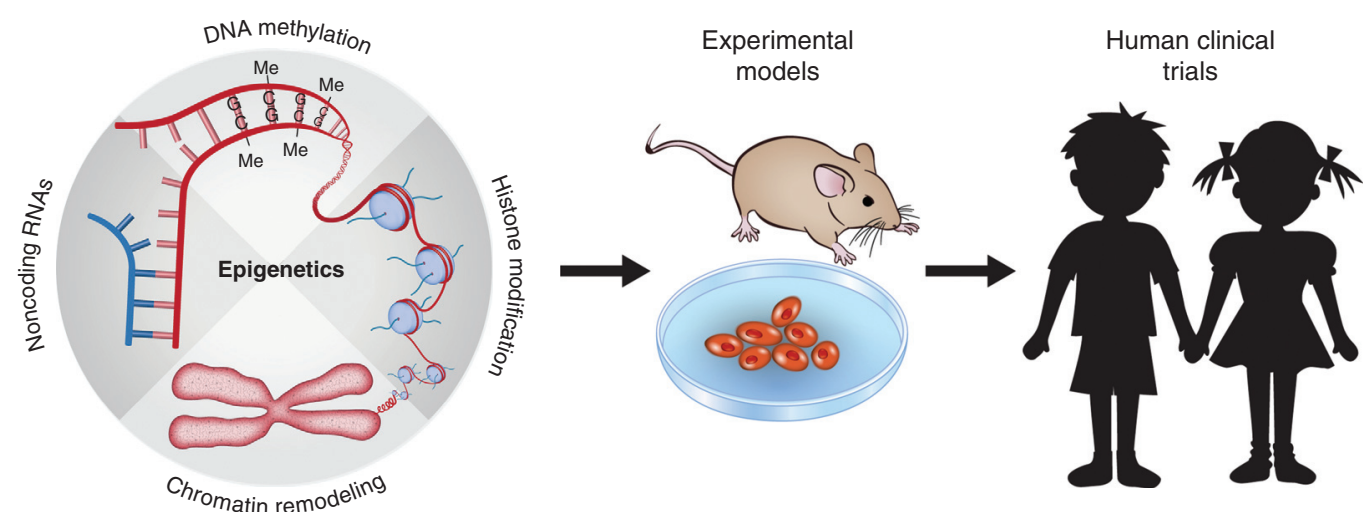

Figure 3. Studies of epigenetic regulation in experimental models. These studies may have a significant impact on the understanding and treatment of human diseases. Insights from animal and in vitro models may guide the development of effective therapeutic treatments (e.g., stem-cell transplantation) or drugs (e.g., inhibitors of histone-modifying enzymes, so-called "epi-drugs") for human neurodevelopmental disorders.

paternal chromosome 15q11-q13 (Powell et al. 2013). Another lncRNA, Gomafu, is involved in schizophrenia-associated alternative splicing (Barry et al. 2013). These emerging studies combining mouse and in vitro cell models with samples from human patients suggest that epigenetic factors contribute to neurodevelopmental disorders and represent a new avenue of therapeutic targets (Fig. 3).

\section{CONCLUSIONS}

The genome is no longer considered a static and privileged storage depot of genetic information, rather it is now recognized to be a highly dynamic entity that undergoes profound structural and functional changes in response to extrinsic signals. Epigenetic and transcriptional regulation of the neuronal genome during adult neurogenesis has emerged as one of the best and most useful paradigms to study the role of chromatin modification in cell-fate specification. After NSPCs are triggered to proliferate, the next step is to determine how master regulators of the neuronal genome interact with their cognate binding partners at sequence-specific binding sites in a context-dependent manner to regulate downstream events controlling neuronal differentiation, survival, and maturation of new neurons. The fact that many epigenetic processes in the cell can act in a reversible and gene- specific manner allows for the precise control of gene expression that is critical for controlling the multiple stages of neurogenesis and function of new neurons in adult neurogenic niches. Moreover, epigenetic processes in developing and mature neural cells appear to be targeted by a number of pathophysiological stimuli, including seizure activity. Although these studies are good starting points for studying epigenetic and transcriptional regulation of neuronal target genes, much work is still needed to fully understand the role of epigenetic regulators of the neuronal genome. Indeed, small chemical compounds and/or ribonucleic acids would provide excellent tools to begin gaining insight into these regulatory mechanisms, and could be the starting points for novel neurological drugs.

\section{ACKNOWLEDGMENTS}

We thank Jose Cabrera for figure illustrations. This work is supported by grants from the National Institutes of Health (NIH) (R01AG032383, K02AG041815, R21MH094715, and R21NS090926 to J.H. and R01MH080434 and R01MH078972 to X.Z.), the Welch Foundation (I-1660 to J.H.), a grant from the Texas Institute for Brain Injury and Repair (to J.H.), the International Rett Syndrome Foundation (IRSF, 2755 to X.Z.), FRAXA (to X.Z.), John Merck Fund (to X.Z.), and a 
Center Grant from the NIH to the Waisman Center (P30HD03352 to X.Z.).

\section{REFERENCES}

Ajamian F, Suuronen T, Salminen A, Reeben M. 2003. Upregulation of class II histone deacetylases mRNA during neural differentiation of cultured rat hippocampal progenitor cells. Neurosci Lett 346: 57-60.

Albert M, Helin K. 2010. Histone methyltransferases in cancer. Semin Cell Dev Biol 21: 209-220.

Allan AM, Liang X, Luo Y, Pak C, Li X, Szulwach KE, Chen D, Jin P, Zhao X. 2008. The loss of methyl-CpG binding protein 1 leads to autism-like behavioral deficits. Hum Mol Genet 17: 2047-2057.

Amir RE, Van den Veyver IB, Wan M, Tran CQ, Francke U, Zoghbi HY. 1999. Rett syndrome is caused by mutations in X-linked $M E C P 2$, encoding methyl-CpG-binding protein 2. Nat Genet 23: 185-188.

Ananiev G, Williams EC, Li H, Chang Q. 2011. Isogenic pairs of wild type and mutant induced pluripotent stem cell (iPSC) lines from Rett syndrome patients as in vitro disease model. PLoS ONE 6: e25255.

Ballas N, Battaglioli E, Atouf F, Andres ME, Chenoweth J, Anderson ME, Burger C, Moniwa M, Davie JR, Bowers WJ, et al. 2001. Regulation of neuronal traits by a novel transcriptional complex. Neuron 31: 353-365.

Barry G, Briggs JA, Vanichkina DP, Poth EM, Beveridge NJ, Ratnu VS, Nayler SP, Nones K, Hu J, Bredy TW, et al. 2013. The long non-coding RNA Gomafu is acutely regulated in response to neuronal activation and involved in schizophrenia-associated alternative splicing. $\mathrm{Mol}$ Psychiatry 19: 486-494.

Bartel DP. 2009. MicroRNAs: Target recognition and regulatory functions. Cell 136: 215-233.

Becker PB, Horz W. 2002. ATP-dependent nucleosome remodeling. Annu Rev Biochem 71: 247-273.

Bernstein BE, Meissner A, Lander ES. 2007. The mammalian epigenome. Cell 128: 669-681.

Biacsi R, Kumari D, Usdin K. 2008. SIRT2 inhibition alleviates gene silencing in Fragile $\mathrm{X}$ mental retardation syndrome. PLoS Genet 4: e1000017.

Bruce AW, Donaldson IJ, Wood IC, Yerbury SA, Sadowski MI, Chapman M, Gottgens B, Buckley NJ. 2004. Genome-wide analysis of repressor element 1 silencing transcription factor/neuron-restrictive silencing factor (REST/NRSF) target genes. Proc Natl Acad Sci 101: 10458-10463.

Cao X, Yeo G, Muotri AR, Kuwabara T, Gage FH. 2006. Noncoding RNAs in the mammalian central nervous system. Annu Rev Neurosci 29: 77-103.

Chen ZX, Riggs AD. 2011. DNA methylation and demethylation in mammals. J Biol Chem 286: 18347-18353.

Cheng L, Pastrana E, Tavazoie M, Doetsch F. 2009. miR-124 regulates adult neurogenesis in the subventricular zone stem cell niche. Nat Neurosci 12: 399-408.

Chiurazzi P, Pomponi MG, Willemsen R, Oostra BA, Neri G. 1998. In vitro reactivation of the FMR1 gene involved in fragile X syndrome. Hum Mol Genet 7: 109-113.
Chiurazzi P, Pomponi MG, Pietrobono R, Bakker CE, Neri G, Oostra BA. 1999. Synergistic effect of histone hyperacetylation and DNA demethylation in the reactivation of the FMR1 gene. Hum Mol Genet 8: 2317-2323.

Coffee B, Zhang F, Warren ST, Reines D. 1999. Acetylated histones are associated with FMR1 in normal but not fragile X-syndrome cells. Nat Genet 22: 98-101.

Chong JA, Tapia-Ramirez J, Kim S, Toledo-Aral JJ, Zheng Y, Boutros MC, Altshuller YM, Frohman MA, Kraner SD, Mandel G. 1995. REST: A mammalian silencer protein that restricts sodium channel gene expression to neurons. Cell 80: 949-957.

Conaco C, Otto S, Han JJ, Mandel G. 2006. Reciprocal actions of REST and a microRNA promote neuronal identity. Proc Natl Acad Sci 103: 2422-2427.

Cui H, Ma J, Ding J, Li T, Alam G, Ding HF. 2006. Bmi-1 regulates the differentiation and clonogenic self-renewal of I-type neuroblastoma cells in a concentration-dependent manner. J Biol Chem 281: 34696-34704.

Cukier HN, Rabionet R, Konidari I, Rayner-Evans MY, Baltos ML, Wright HH, Abramson RK, Martin ER, Cuccaro ML, Pericak-Vance MA, et al. 2010. Novel variants identified in methyl-CpG-binding domain genes in autistic individuals. Neurogenetics 11: 291-303.

Defossez PA, Stancheva I. 2011. Biological functions of methyl-CpG-binding proteins. Prog Mol Biol Transl Sci 101: 377-398.

De Pietri Tonelli D, Pulvers JN, Haffner C, Murchison EP, Hannon GJ, Huttner WB. 2008. miRNAs are essential for survival and differentiation of newborn neurons but not for expansion of neural progenitors during early neurogenesis in the mouse embryonic neocortex. Development 135: 3911-3921.

de Ruijter AJ, van Gennip AH, Caron HN, Kemp S, van Kuilenburg AB. 2003. Histone deacetylases (HDACs): Characterization of the classical HDAC family. Biochem J 370: 737-749.

Fan G, Beard C, Chen RZ, Csankovszki G, Sun Y, Siniaia M, Biniszkiewicz D, Bates B, Lee PP, Kuhn R, et al. 2001. DNA hypomethylation perturbs the function and survival of CNS neurons in postnatal animals. J Neurosci 21: 788-797.

Fan G, Martinowich K, Chin MH, He F, Fouse SD, Hutnick L, Hattori D, Ge W, Shen Y, Wu H, et al. 2005. DNA methylation controls the timing of astrogliogenesis through regulation of JAK-STAT signaling. Development 132: 3345-3356.

Farra N, Zhang WB, Pasceri P, Eubanks JH, Salter MW, Ellis J. 2012. Rett syndrome induced pluripotent stem cellderived neurons reveal novel neurophysiological alterations. Mol Psychiatry 17: 1261-1271.

Feenstra I, Vissers LE, Orsel M, van Kessel AG, Brunner HG, Veltman JA, van Ravenswaaij-Arts CM. 2007. Genotypephenotype mapping of chromosome 18q deletions by high-resolution array CGH: An update of the phenotypic map. Am J Med Genet A 143A: 1858-1867.

Feng J, Chang H, Li E, Fan G. 2005. Dynamic expression of de novo DNA methyltransferases Dnmt3a and Dnmt3b in the central nervous system. J Neurosci Res 79: 734-746.

Feng J, Zhou Y, Campbell SL, Le T, Li E, Sweatt JD, Silva AJ, Fan G. 2010. Dnmt1 and Dnmt3a maintain DNA meth- 
ylation and regulate synaptic function in adult forebrain neurons. Nat Neurosci 13: 423-430.

Gage FH. 2000. Mammalian neural stem cells. Science 287: $1433-1438$.

Gao Z, Ure K, Ding P, Nashaat M, Yuan L, Ma J, Hammer RE, Hsieh J. 2011. The master negative regulator REST/ NRSF controls adult neurogenesis by restraining the neurogenic program in quiescent stem cells. J Neurosci 31: 9772-9786.

Garriga-Canut M, Schoenike B, Qazi R, Bergendahl K, Daley TJ, Pfender RM, Morrison JF, Ockuly J, Stafstrom C, Sutula T. 2006. 2-Deoxy-D-glucose reduces epilepsy progression by NRSF-CtBP-dependent metabolic regulation of chromatin structure. Nat Neurosci 9: 1382-1387.

Greenway DJ, Street M, Jeffries A, Buckley NJ. 2006. REST maintains a repressive chromatin environment in embryonic hippocampal neural stem cells. Stem Cells 25: $354-$ 363.

Grozinger CM, Schreiber SL. 2002. Deacetylase enzymes: Biological functions and the use of small-molecule inhibitors. Chem Biol 9: 3-16.

Guan JS, Haggarty SJ, Giacometti E, Dannenberg JH, Joseph N, Gao J, Nieland TJ, Zhou Y, Wang X, Mazitschek R, et al. 2009. HDAC2 negatively regulates memory formation and synaptic plasticity. Nature 459: 55-60.

Guillemot F. 2005. Cellular and molecular control of neurogenesis in the mammalian telencephalon. Curr Opin Cell Biol 17: 639-647.

Guo JU, Ma DK, Mo H, Ball MP, Jang MH, Bonaguidi MA, Balazer JA, Eaves HL, Xie B, Ford E, et al. 2011a. Neuronal activity modifies the DNA methylation landscape in the adult brain. Nat Neurosci 14: 1345-1351.

Guo JU, Su Y, Zhong C, Ming GL, Song H. 2011b. Hydroxylation of 5-methylcytosine by TET1 promotes active DNA demethylation in the adult brain. Cell 145: 423434.

Guo W, Allan AM, Zong R, Zhang L, Johnson EB, Schaller EG, Murthy AC, Goggin SL, Eisch AJ, Oostra BA, et al. 2011c. Ablation of Fmrp in adult neural stem cells disrupts hippocampus-dependent learning. Nat Med 17: 559-565.

Guo W, Murthy AC, Zhang L, Johnson EB, Schaller EG, Allan AM, Zhao X. 2012. Inhibition of GSK3 $\beta$ improves hippocampus-dependent learning and rescues neurogenesis in a mouse model of fragile X syndrome. Hum Mol Genet 21: 681-691.

Guo W, Polich ED, Juan Su J, Gao Y, Christopher DM, Allan AM, Wang M, Wang F, Wang G, Zhao X. 2015. Fragile X proteins FMRP and FXR2P control synaptic GluA1 expression and neuronal maturation via distinct mechanisms. Cell Rep 11: 1651-1666.

Guy J, Hendrich B, Holmes M, Martin JE, Bird A. 2001. A mouse Mecp2-null mutation causes neurological symptoms that mimic Rett syndrome. Nat Genet 27: 322-326.

Haberland M, Carrer M, Mokalled MH, Montgomery RL, Olson EN. 2010. Redundant control of adipogenesis by histone deacetylases 1 and 2. J Biol Chem 285: 1466314670.

Hao Y, Creson T, Zhang L, Li P, Du F, Yuan P, Gould T, Manji H, Chen G. 2004. Mood stabilizer valproate promotes
ERK pathway-dependent cortical neuronal growth and neurogenesis. J Neurosci 24: 6590-6599.

Harikrishnan KN, Chow MZ, Baker EK, Pal S, Bassal S, Brasacchio D, Wang L, Craig JM, Jones PL, Sif S, et al. 2005. Brahma links the SWI/SNF chromatin-remodeling complex with MeCP2-dependent transcriptional silencing. Nat Genet 37: 254-264.

Hodge RD, Kahoud RJ, Hevner RF. 2012. Transcriptional control of glutamatergic differentiation during adult neurogenesis. Cell Mol Life Sci 69: 2125-2134.

Hong S, Cho YW, Yu LR, Yu H, Veenstra TD, Ge K. 2007. Identification of JmjC domain-containing UTX and JMJD3 as histone H3 lysine 27 demethylases. Proc Natl Acad Sci 104: 18439-18444.

Hsieh J. 2012. Orchestrating transcriptional control of adult neurogenesis. Genes Dev 26: 1010-1021.

Hsieh J, Nakashima K, Kuwabara T, Mejia E, Gage FH. 2004. Histone deacetylase inhibition-mediated neuronal differentiation of multipotent adult neural progenitor cells. Proc Natl Acad Sci 101: 16659-16664.

Issaeva I, Zonis Y, Rozovskaia T, Orlovsky K, Croce CM, Nakamura T, Mazo A, Eisenbach L, Canaani E. 2007. Knockdown of ALR (MLL2) reveals ALR target genes and leads to alterations in cell adhesion and growth Mol Cell Biol 27: 1889-1903.

Jaenisch R, Bird A. 2003. Epigenetic regulation of gene expression: How the genome integrates intrinsic and environmental signals. Nat Genet 33: 245-254.

Jawerka M, Colak D, Dimou L, Spiller C, Lagger S, Montgomery RL, Olson EN, Wurst W, Gottlicher M, Gotz M. 2010. The specific role of histone deacetylase 2 in adult neurogenesis. Neuron Glia Biol 6: 93-107.

Jenuwein T, Allis CD. 2001. Translating the histone code. Science 293: 1074-1080.

Jepsen K, Hermanson O, Onami TM, Gleiberman AS, Lunyak V, McEvilly RJ, Kurokawa R, Kumar V, Liu F, Seto E, et al. 2000. Combinatorial roles of the nuclear receptor corepressor in transcription and development. Cell 102: 753-763.

Jiang Y, Hsieh J. 2014. HDAC3 controls gap 2/mitosis progression in adult neural stem/progenitor cells by regulating CDK1 levels. Proc Natl Acad Sci 111: 13541-13546.

Jobe EM, McQuate AL, Zhao X. 2012. Crosstalk among epigenetic pathways regulates neurogenesis. Front Neurosci 6: 59.

Jung BP, Jugloff DG, Zhang G, Logan R, Brown S, Eubanks JH. 2003. The expression of methyl CpG binding factor MeCP2 correlates with cellular differentiation in the developing rat brain and in cultured cells. J Neurobiol 55: 86-96.

Kato Z, Morimoto W, Kimura T, Matsushima A, Kondo N. 2010. Interstitial deletion of 18q: Comparative genomic hybridization array analysis of $46, \mathrm{XX}, \operatorname{del}(18)$ (q21.2.q21.33). Birth Defects Res A Clin Mol Teratol 88: $132-135$.

Kim JE, O’Sullivan ML, Sanchez CA, Hwang M, Israel MA, Brennand K, Deerinck TJ, Goldstein LS, Gage FH, Ellisman $\mathrm{MH}$, et al. 2011. Investigating synapse formation and function using human pluripotent stem cell-derived neurons. Proc Natl Acad Sci 108: 3005-3010. 
J. Hsieh and X. Zhao

Knuckles P, Vogt MA, Lugert S, Milo M, Chong MM, Hautbergue GM, Wilson SA, Littman DR, Taylor V. 2012. Drosha regulates neurogenesis by controlling neurogenin 2 expression independent of microRNAs. Nat Neurosci 15: 962-969.

Koh KP, Rao A. 2013. DNA methylation and methylcytosine oxidation in cell fate decisions. Curr Opin Cell Biol 25: $152-161$.

Krol J, Loedige I, Filipowicz W. 2010. The widespread regulation of microRNA biogenesis, function and decay. Nat Rev Genet 11: 597-610.

Lee TI, Jenner RG, Boyer LA, Guenther MG, Levine SS, Kumar RM, Chevalier B, Johnstone SE, Cole MF, Isono $\mathrm{K}$, et al. 2006. Control of developmental regulators by Polycomb in human embryonic stem cells. Cell 125: 301-313.

Lessard J, Wu JI, Ranish JA, Wan M, Winslow MM, Staahl BT, Wu H, Aebersold R, Graef IA, Crabtree GR. 2007. An essential switch in subunit composition of a chromatin remodeling complex during neural development. Neuron 55: 201-215.

Levenson JM, Roth TL, Lubin FD, Miller CA, Huang IC, Desai P, Malone LM, Sweatt JD. 2006. Evidence that DNA (cytosine-5) methyltransferase regulates synaptic plasticity in the hippocampus. J Biol Chem 281: 15763-15773.

Li X, Zhao X. 2008. Epigenetic regulation of mammalian stem cells. Stem Cells Dev 17: 1043-1052.

Li H, Yamagata T, Mori M, Yasuhara A, Momoi MY. 2005. Mutation analysis of methyl-CpG binding protein family genes in autistic patients. Brain Dev 27: 321-325.

Li X, Barkho B, Luo Y, Smrt R, Santistevan N, Liu C, Kuwabara T, Gage F, Zhao X. 2008. Epigenetic regulation of the stem cell mitogen Fgf- 2 by Mbd1 in adult neural stem/ progenitor cells. J Biol Chem 283: 27644-27652.

Lim DA, Huang YC, Swigut T, Mirick AL, Garcia-Verdugo JM, Wysocka J, Ernst P, Alvarez-Buylla A. 2009. Chromatin remodelling factor Mll1 is essential for neurogenesis from postnatal neural stem cells. Nature 458: 529-533.

Liu C, Teng ZQ, Santistevan NJ, Szulwach KE, Guo W, Jin P, Zhao X. 2010. Epigenetic regulation of miR-184 by MBD1 governs neural stem cell proliferation and differentiation. Cell Stem Cell 6: 433-444.

Liu XS, Chopp M, Zhang RL, Tao T, Wang XL, Kassis H, Hozeska-Solgot A, Zhang L, Chen C, Zhang ZG. 2011. MicroRNA profiling in subventricular zone after stroke: MiR-124a regulates proliferation of neural progenitor cells through Notch signaling pathway. PLOS ONE 6: e23461.

Liu C, Teng ZQ, McQuate AL, Jobe EM, Christ CC, von Hoyningen-Huene SJ, Reyes MD, Polich ED, Xing Y, Li Y, et al. 2013. An epigenetic feedback regulatory loop involving microRNA-195 and MBD1 governs neural stem cell differentiation. PLOS ONE 8: e51436.

Long JE, Garel S, Alvarez-Dolado M, Yoshikawa K, Osumi N, Alvarez-Buylla A, Rubenstein JL. 2007. Dlx-dependent and -independent regulation of olfactory bulb interneuron differentiation. J Neurosci 27: 3230-3243.

Luger K, Richmond TJ. 1998. The histone tails of the nucleosome. Curr Opin Genet Dev 8: 140-146.
Luo Y, Shan G, Guo W, Smrt RD, Johnson EB, Li X, Pfeiffer RL, Szulwach KE, Duan R, Barkho BZ, et al. 2010. Fragile $\mathrm{X}$ mental retardation protein regulates proliferation and differentiation of adult neural stem/progenitor cells. PLoS Genet 6: e1000898.

Ma DK, Jang MH, Guo JU, Kitabatake Y, Chang ML, PowAnpongkul N, Flavell RA, Lu B, Ming GL, Song H. 2009. Neuronal activity-induced Gadd45b promotes epigenetic DNA demethylation and adult neurogenesis. Science 323: $1074-1077$

MacDonald JL, Roskams AJ. 2008. Histone deacetylases 1 and 2 are expressed at distinct stages of neuro-glial development. Dev Dyn 237: 2256-2267.

Makeyev E, Zhang J, Carrasco M, Maniatis T. 2007. The microRNA miR-124 promotes neuronal differentiation by triggering brain-specific alternative pre-mRNA splicing. Mol Cell 27: 435-448.

Marchetto MC, Carromeu C, Acab A, Yu D, Yeo GW, Mu Y, Chen G, Gage FH, Muotri AR. 2010. A model for neural development and treatment of Rett syndrome using human induced pluripotent stem cells. Cell 143: 527-539.

Mercer TR, Dinger ME, Sunkin SM, Mehler MF, Mattick JS. 2008. Specific expression of long noncoding RNAs in the mouse brain. Proc Natl Acad Sci 105: 716-721.

Ming GL, Song H. 2005. Adult neurogenesis in the mammalian central nervous system. Annu Rev Neurosci 28: 223-250.

Mohn F, Weber M, Rebhan M, Roloff TC, Richter J, Stadler MB, Bibel M, Schubeler D. 2008. Lineage-specific polycomb targets and de novo DNA methylation define restriction and potential of neuronal progenitors. Mol Cell 30: 755-766.

Molofsky AV, Pardal R, Iwashita T, Park IK, Clarke MF, Morrison SJ. 2003. Bmi-1 dependence distinguishes neural stem cell self-renewal from progenitor proliferation. $\mathrm{Na}$ ture 425: 962-967.

Montgomery RL, Hsieh J, Barbosa AC, Richardson JA, Olson EN. 2009. Histone deacetylases 1 and 2 control the progression of neural precursors to neurons during brain development. Proc Natl Acad Sci 106: 7876-7881.

Mosammaparast N, Shi Y. 2010. Reversal of histone methylation: Biochemical and molecular mechanisms of histone demethylases. Annu Rev Biochem 79: 155-179.

Namihira M, Nakashima K, Taga T. 2004. Developmental stage dependent regulation of DNA methylation and chromatin modification in an immature astrocyte specific gene promoter. FEBS Lett 572: 184-188.

Naruse Y, Aoki T, Kojima T, Mori N. 1999. Neural restrictive silencer factor recruits $\mathrm{mSin} 3$ and histone deacetylase complex to repress neuron-specific target genes. Proc Natl Acad Sci 96: 13691-13696.

Neul JL, Fang P, Barrish J, Lane J, Caeg EB, Smith EO, Zoghbi H, Percy A, Glaze DG. 2008. Specific mutations in methyl-CpG-binding protein 2 confer different severity in Rett syndrome. Neurology 70: 1313-1321.

Ng SY, Bogu GK, Soh BS, Stanton LW. 2013a. The long noncoding RNA RMST interacts with SOX2 to regulate neurogenesis. Mol Cell 51: 349-359.

Ng SY, Lin L, Soh BS, Stanton LW. 2013b. Long noncoding RNAs in development and disease of the central nervous system. Trends Genet 29: 461-468. 
Nimura K, Ura K, Kaneda Y. 2010. Histone methyltransferases: Regulation of transcription and contribution to human disease. J Mol Med 88: 1213-1220.

Ninkovic J, Steiner-Mezzadri A, Jawerka M, Akinci U, Masserdotti G, Petricca S, Fischer J, von Holst A, Beckers J, Lie CD, et al. 2013. The BAF complex interacts with Pax6 in adult neural progenitors to establish a neurogenic crossregulatory transcriptional network. Cell Stem Cell 13: 403-418.

Novina CD, Sharp PA. 2004. The RNAi revolution. Nature 430: $161-164$

Ooi SK, O'Donnell AH, Bestor TH. 2009. Mammalian cytosine methylation at a glance. J Cell Sci 122: 2787-2791.

Ouchi Y, Banno Y, Shimizu Y, Ando S, Hasegawa H, Adachi K, Iwamoto T. 2013. Reduced adult hippocampal neurogenesis and working memory deficits in the $\mathrm{Dgcr} 8$-deficient mouse model of 22q11.2 deletion-associated schizophrenia can be rescued by IGF2. J Neurosci 33: $9408-$ 9419.

Park CY, Choi YS, McManus MT. 2010. Analysis of microRNA knockouts in mice. Hum Mol Genet 19: R169R175.

Pedersen MT, Helin K. 2010. Histone demethylases in development and disease. Trends Cell Biol 20: 662-671.

Powell WT, Coulson RL, Crary FK, Wong SS, Ach RA, Tsang P, Alice Yamada N, Yasui DH, Lasalle JM. 2013. A PraderWilli locus lncRNA cloud modulates diurnal genes and energy expenditure. Hum Mol Genet 22: 4318-4328.

Qureshi IA, Mehler MF. 2013. Long non-coding RNAs: Novel targets for nervous system disease diagnosis and therapy. Neurotherapeutics 10: 632-646.

Ramos AD, Diaz A, Nellore A, Delgado RN, Park KY, Gonzales-Roybal G, Oldham MC, Song JS, Lim DA. 2013. Integration of genome-wide approaches identifies lncRNAs of adult neural stem cells and their progeny in vivo. Cell Stem Cell 12: 616-628.

Rett A. 1966. On a unusual brain atrophy syndrome in hyperammonemia in childhood. Wien Med Wochenschr 116: $723-726$.

Ross SE, Greenberg ME, Stiles CD. 2003. Basic helix-loophelix factors in cortical development. Neuron 39: 13-25.

Schneider JW, Gao Z, Li S, Farooqi M, Tang TS, Bezprozvanny I, Frantz DE, Hsieh J. 2008. Small-molecule activation of neuronal cell fate. Nat Chem Biol 4: 408-410.

Schoenherr CJ, Anderson DJ. 1995. The neuron-restrictive silencer factor (NRSF): A coordinate repressor of multiple neuron-specific genes. Science 267: 1360-1363.

Shen L, Zhang Y. 2013. 5-Hydroxymethylcytosine: Generation, fate, and genomic distribution. Curr Opin Cell Biol 25: $289-296$.

Shi Y, Chichung Lie D, Taupin P, Nakashima K, Ray J, Yu RT, Gage FH, Evans RM. 2004a. Expression and function of orphan nuclear receptor TLX in adult neural stem cells. Nature 427: 78-83.

Shi Y, Lan F, Matson C, Mulligan P, Whetstine JR, Cole PA, Casero RA. 2004b. Histone demethylation mediated by the nuclear amine oxidase homolog LSD1. Cell 119: 941-953.

Smrt R, Eaves-Egenes J, Barkho B, Santistevan N, Zhao C, Aimone J, Gage F, Zhao X. 2007. Mecp2 deficiency leads to delayed maturation and altered gene expression in hippocampal neurons. Neurobiol Dis 27: 77-89.

Smrt RD, Szulwach KE, Pfeiffer RL, Li X, Guo W, Pathania M, Teng ZQ, Luo Y, Peng J, Bordey A, et al. 2010. MicroRNA miR-137 regulates neuronal maturation by targeting ubiquitin ligase mind bomb-1. Stem Cells 28: 10601070.

Smrt RD, Pfeiffer RL, Zhao X. 2011. Age-dependent expression of MeCP2 in a heterozygous mosaic mouse model. Hum Mol Genet 20: 1834-1843.

Sun YM, Greenway DJ, Johnson R, Street M, Belyaev ND, Deuchars J, Bee T, Wilde S, Buckley NJ. 2005. Distinct profiles of REST interactions with its target genes at different stages of neuronal development. Mol Biol Cell 16: 5630-5638.

Sun G, Yu RT, Evans RM, Shi Y. 2007. Orphan nuclear receptor TLX recruits histone deacetylases to repress transcription and regulate neural stem cell proliferation. Proc Natl Acad Sci 104: 15282-15287.

Sun G, Alzayady K, Stewart R, Ye P, Yang S, Li W, Shi Y. 2010. Histone demethylase LSD1 regulates neural stem cell proliferation. Mol Cell Biol 30: 1997-2005.

Szulwach KE, Li X, Smrt RD, Li Y, Luo Y, Lin L, Santistevan NJ, Li W, Zhao X, Jin P. 2010. Cross talk between microRNA and epigenetic regulation in adult neurogenesis. $J$ Cell Biol 189: 127-141.

Szulwach KE, Li X, Li Y, Song CX, Wu H, Dai Q, Irier H, Upadhyay AK, Gearing M, Levey AI, et al. 2011. 5-hmCmediated epigenetic dynamics during postnatal neurodevelopment and aging. Nat Neurosci 14: 1607-1616.

Tabolacci E, Pietrobono R, Moscato U, Oostra BA, Chiurazzi P, Neri G. 2005. Differential epigenetic modifications in the FMR 1 gene of the fragile $\mathrm{X}$ syndrome after reactivating pharmacological treatments. Eur J Hum Genet 13: 641-648.

Tabolacci E, De Pascalis I, Accadia M, Terracciano A, Moscato U, Chiurazzi P, Neri G. 2008. Modest reactivation of the mutant FMR1 gene by valproic acid is accompanied by histone modifications but not DNA demethylation. Pharmacogenet Genomics 18: 738-741.

Takizawa T, Nakashima K, Namihira M, Ochiai W, Uemura A, Yanagisawa M, Fujita N, Nakao M, Taga T. 2001. DNA methylation is a critical cell-intrinsic determinant of astrocyte differentiation in the fetal brain. Dev Cell 1: 749758.

Temple S. 2001. The development of neural stem cells. $\mathrm{Na}$ ture 414: 112-117.

Torres-Padilla ME, Parfitt DE, Kouzarides T, ZernickaGoetz M. 2007. Histone arginine methylation regulates pluripotency in the early mouse embryo. Nature 445: 214-218.

Visvanathan J, Lee S, Lee B, Lee J, Lee S. 2007. The microRNA miR-124 antagonizes the anti-neural REST/SCP1 pathway during embryonic CNS development. Genes Dev 21: 744-749.

Wang KC, Chang HY. 2011. Molecular mechanisms of long noncoding RNAs. Mol Cell 43: 904-914.

Wang T, Pan Q, Lin L, Szulwach KE, Song CX, He C, Wu H, Warren ST, Jin P, Duan R, et al. 2012. Genome-wide DNA hydroxymethylation changes are associated with neuro- 
J. Hsieh and X. Zhao

developmental genes in the developing human cerebellum. Hum Mol Genet 21: 5500-5510.

Wapinski O, Chang HY. 2011. Long noncoding RNAs and human disease. Trends Cell Biol 21: 354-361.

Ye F, Chen Y, Hoang T, Montgomery RL, Zhao XH, Bu H, Hu T, Taketo MM, van Es JH, Clevers H, et al. 2009. HDAC1 and HDAC2 regulate oligodendrocyte differentiation by disrupting the $\beta$-catenin-TCF interaction. Nat Neurosci 12: $829-838$.

Yoo AS, Staahl BT, Chen L, Crabtree GR. 2009. MicroRNAmediated switching of chromatin-remodelling complexes in neural development. Nature 460: 642-646.

Zhang CL, Zou Y, He W, Gage FH, Evans RM. 2008. A role for adult TLX-positive neural stem cells in learning and behaviour. Nature 451: 1004-1007.
Zhang RR, Cui QY, Murai K, Lim YC, Smith ZD, Jin S, Ye P Rosa L, Lee YK, Wu HP, et al. 2013. Tet1 regulates adult hippocampal neurogenesis and cognition. Cell Stem Cell 13: $237-245$.

Zhao X, Ueba T, Christie BR, Barkho B, McConnell MJ, Nakashima K, Lein ES, Eadie BD, Willhoite AR, Muotri A, et al. 2003. Mice lacking methyl-CpG binding protein 1 have deficits in adult neurogenesis and hippocampal function. Proc Natl Acad Sci 100: 67776782.

Ziats MN, Rennert OM. 2013. Aberrant expression of long noncoding RNAs in autistic brain. J Mol Neurosci 49: 589-593.

Zoghbi HY. 2003. Postnatal neurodevelopmental disorders: Meeting at the synapse? Science 302: 826-830. 


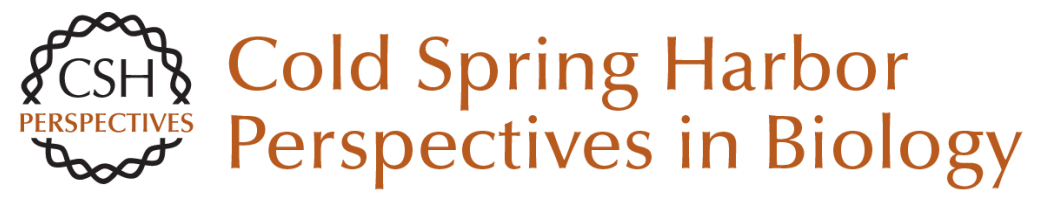

\section{Genetics and Epigenetics in Adult Neurogenesis}

Jenny Hsieh and Xinyu Zhao

Cold Spring Harb Perspect Biol 2016; doi: 10.1101/cshperspect.a018911 originally published online May 3, 2016

\section{Subject Collection Neurogenesis}

Adult Neurogenesis and Psychiatric Disorders Eunchai Kang, Zhexing Wen, Hongjun Song, et al.

Neuronal Circuitry Mechanisms Regulating Adult Mammalian Neurogenesis Juan Song, Reid H.J. Olsen, Jiaqi Sun, et al.

Neurogenesis in the Developing and Adult Brain

--Similarities and Key Differences

Magdalena Götz, Masato Nakafuku and David Petrik

Genetics and Epigenetics in Adult Neurogenesis Jenny Hsieh and Xinyu Zhao

The Adult Ventricular-Subventricular Zone (V-SVZ) and Olfactory Bulb (OB) Neurogenesis Daniel A. Lim and Arturo Alvarez-Buylla

Diversity of Neural Precursors in the Adult Mammalian Brain Michael A. Bonaguidi, Ryan P. Stadel, Daniel A. Berg, et al.

Detection and Phenotypic Characterization of Adult Neurogenesis $H$. Georg Kuhn, Amelia J. Eisch, Kirsty Spalding, et al.

Maturation and Functional Integration of New Granule Cells into the Adult Hippocampus Nicolas Toni and Alejandro F. Schinder
Adult Olfactory Bulb Neurogenesis

Pierre-Marie Lledo and Matt Valley

Adult Neurogenesis in Fish Julia Ganz and Michael Brand

In Vitro Models for Neurogenesis Hassan Azari and Brent A. Reynolds
Engineering of Adult Neurogenesis and Gliogenesis
Benedikt Berninger and Sebastian Jessberger
Computational Modeling of Adult Neurogenesis James B. Aimone
Control of Adult Neurogenesis by Short-Range Morphogenic-Signaling Molecules Youngshik Choe, Samuel J. Pleasure and Helena Mira

Adult Neurogenesis: An Evolutionary Perspective Gerd Kempermann

Epilepsy and Adult Neurogenesis

Sebastian Jessberger and Jack M. Parent

For additional articles in this collection, see http://cshperspectives.cshlp.org/cgi/collection/

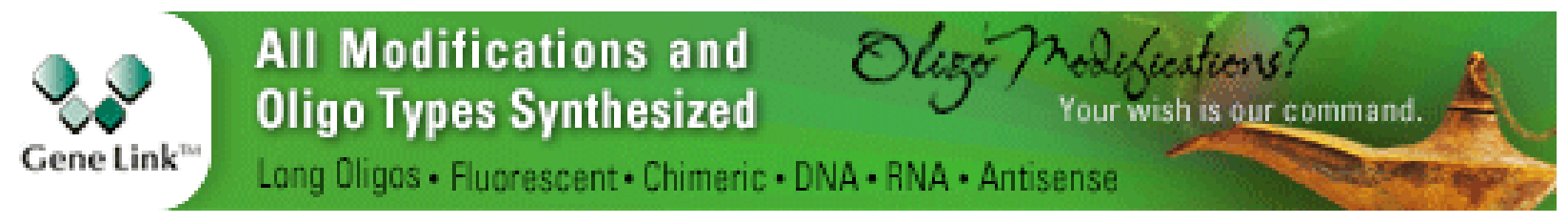


For additional articles in this collection, see http://cshperspectives.cshlp.org/cgi/collection/

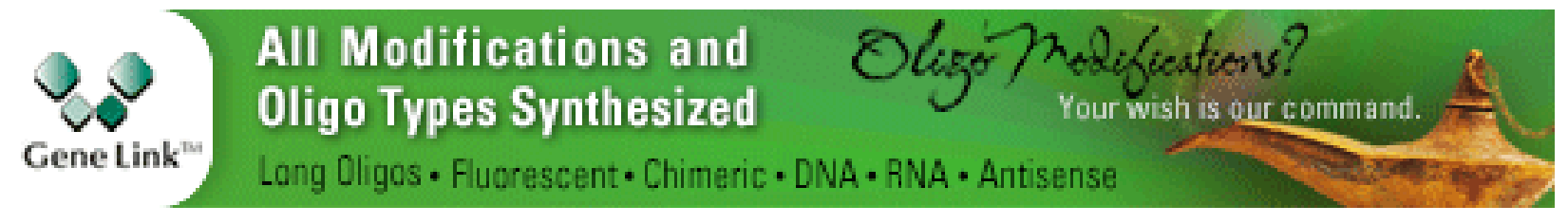

Copyright @ 2016 Cold Spring Harbor Laboratory Press; all rights reserved 